\title{
Flushing Problem
}

National Cancer Institute

\section{Source}

National Cancer Institute. Flushing Problem. NCI Thesaurus. Code C63176.

Flushing process was not executed properly. 